\title{
Obituary of Professor Kazuyoshi Tsutsui
}

Prof. Kazuyoshi Tsutsui passed away on September 16, 2021, aged 68 years. Kazuyoshi Tsutsui was born on September 30, 1952, in Hiroshima, Japan. Ever since his time in junior high school, he was greatly interested in biology, especially in the metabolic and endocrine systems. He entered the Department of Biology at Waseda University, Tokyo, Japan in 1972. He graduated from the University and entered its graduate school in 1976. He was awarded the degree of Doctor of Science as the representative of all $\mathrm{PhD}$ students from Waseda University in 1981. He mainly studied the effect of follicle-stimulating hormone and testosterone on the testis of Japanese quail during his graduate school years under the supervision of Prof. Susumu Ishii. He also studied and published the effects of sex steroids on the aggressive behavior of adult male quail, which is a work that is still frequently cited [1].

He was then employed by the Faculty of Science at Hiroshima University as a Research Associate under Prof. Seiichiro Kawashima in 1983. He was also a Postdoctoral Scholar of the Department of Neuroscience, University of Southern California, USA, from 1988 to 1989. Later, he was employed by Kobe University School of Medicine as an Assistant Professor in 1991. There, he developed his studies on gonadotropins in mammals, such as rats, mice, and hamsters $[2,3]$. He was also interested in the seasonal regulation of the endocrine system and used songbirds as models $[4,5]$.

Prof. Tsutsui was employed by the Faculty of Integrated Arts and Sciences at Hiroshima University as an Associate Professor in 1993, and was promoted to Professor

karger@karger.com

(c) 2021 S. Karger AG, Basel

www.karger.com/nen

Karger" in 1996. He was also the Director of the Center for Integrative Brain Sciences at Hiroshima University in 2000. It was during this time when he first discovered that neurons in the brain biosynthesize various neurosteroids de novo in birds and mammals [6-8]. He was also interested in the identification and functional analysis of various neuropeptides during this time [9-11].

$\mathrm{He}$ discovered gonadotropin-inhibitory hormone $(\mathrm{GnIH})$ from the quail brain and demonstrated its inhibitory effect on gonadotropin release from the quail pituitary in 2000 [12]. The location of GnIH neurons and GnIH neuronal fiber distribution was studied in detail in the quail brain [13] and the GnIH receptor was also identified [14]. It was also shown that GnIH inhibits gonadal development and maintenance by inhibiting gonadotropin synthesis and release in the male quail [15]. It was further demonstrated that a pineal hormone melatonin induces the expression of GnIH in the quail brain [16].

Prof. Tsutsui also studied the physiological function of neurosteroids in the brain, such as the effects of progesterone and estrogen on the development of Purkinje neurons [17-19]. He further identified a novel neurosteroid,

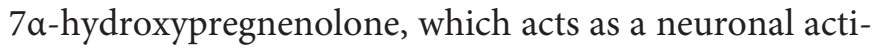
vator of locomotion by means of the dopaminergic system in newts [20].

In 2006, Prof. Tsutsui returned to the Department of Biology, Waseda University, after Prof. Sakae Kikuyama's retirement. He continued studies on GnIH mainly through collaboration with not only Japanese but also foreign scientists. The inhibitory effect of GnIH on go- 
nadotropin release in mammals was first shown in hamsters by collaboration with scientists at the University of California at Berkeley [21]. GnIH was identified and their physiological functions were shown in hamsters [22], sheep [23], macaque monkeys [24], and humans [25]. It was also shown that GnIH has inhibitory effects on sociosexual behavior in birds [26-28] and mammals [29, 30]. The molecular mechanism of the inhibitory effect of $\mathrm{GnIH}$ on gonadotropin gene expression was shown in immortalized gonadotrope cells [31].

It was suggested from morphological studies that $\mathrm{GnIH}$ regulates $\mathrm{GnRH}$ neurons by direct innervation and expression of the $\mathrm{GnIH}$ receptor on $\mathrm{GnRH}$ neurons in birds [32] and mammals [22]. The direct effect of GnIH on $\mathrm{GnRH}$ expression and release was clearly shown using immortalized GnRH cells [33]. It was also shown that melatonin not only stimulates $\mathrm{GnIH}$ expression but also its release in quail [34]. Interestingly, the expression of $\mathrm{GnIH}$ was stimulated by stress and corticosterone, suggesting that $\mathrm{GnIH}$ is involved in the inhibitory mechanism of stress in reproduction [35]. GnIH was also expressed in gonads and regulates sex steroids biosynthesis in birds [36] and mammals [37]. Prof. Tsutsui was also interested in the molecular evolution of GnIH [38-41].

He continued the studies of neurosteroids and found that $7 a$-hydroxypregnenolone mediates melatonin action on diurnal locomotor rhythms [42]. It was shown that $7 a$-hydroxypregnenolone might stimulate upstream migration by means of the dopaminergic system in salmon [43]. He studied the effect of pineal allopregnanolone on Purkinje cell survival [44] and brain development [45]. He was also interested in kisspeptin, a neuropeptide that stimulates GnRH neurons [46, 47]. Recent studies of $\mathrm{GnIH}$ by Prof. Tsutsui include the effect of norepinephrine and thyroid hormones on $\mathrm{GnIH}$ expression and release $[48,49]$.

Prof. Tsutsui became the Emeritus Professor of Hiroshima University in 2013 and returned to the Graduate School of Integrated Sciences for Life at Hiroshima University as a Specially Appointed Professor in 2020. He received numerous honors during his career, including the Zoological Society Prize from the Zoological Society of Japan in 2001, Yoshimura Prize from the Japan Society for Pituitary Research in 2008, Farner Medal from the International Society for Avian Endocrinology in 2008, Masao Ito Best Presentation Award from the Society for Research on the Cerebellum in 2011, Bargmann-Scharrer Award from the International Federation of Comparative Endocrinological Societies (IFCES) in 2013, Okuma Prize for Science and Technology from Waseda University in
2015, Prize for Science and Technology, The Commendation for Science and Technology from the Minister of Education, Culture, Sports, Science, and Technology, Japan in 2015, and Kobayashi Award from the Japan Society for Comparative Endocrinology in 2016.

Prof. Tsutsui was very committed to various Japanese and international scientific organizations. He was President of the Japan Society for Pituitary Research in 2005, Vice-President of the Zoological Society of Japan from 2016 to 2018, President of the Japan Society for Avian Endocrinology from 2006, President of the Japan Society for Comparative Endocrinology from 2006 to 2010, President of the Asia and Oceania Society for Comparative Endocrinology from 2009 to 2018, President of the International Society for Avian Endocrinology from 2013 to 2016, Vice-President of the International Federation of Comparative Endocrinological Societies from 2013 to 2016, and President of the International Federation of Comparative Endocrinological Societies from 2017.

He was also a member of the editorial board of various scientific journals, such as Neuroendocrinology Letters, Zoological Science, Japanese Journal of Reproductive Endocrinology, Animal Cells and Systems, Journal of Experimental Neuroscience, Open Journal of Neuroscience, Clinical Immunology, Endocrine and Metabolic Drugs, Hormonal Studies, BioMed Research International, Physiology Journal, PeerJ, Journal of Neuroendocrinology, Endocrinology, General and Comparative Endocrinology, Frontiers in Integrative Pharmacology, Frontiers in Neuroendocrine Science, Frontiers in Experimental Endocrinology, Brain, Behavior and Immunity, Scientific Reports, The European Journal of Zoology, and Current Neurobiology. He was the Editor-in-Chief of Comparative Endocrinology from 2000 to 2005, Editor-in-Chief of the Japanese Journal of Reproductive Endocrinology from 2008 to 2019, and Editor-in-Chief of Neuroendocrinology from 2020.

He supervised seven $\mathrm{PhD}$ students, Kazuyoshi Ukena, Dan Li, Hirotaka Sakamoto, Takayoshi Ubuka, Masahiro Matsunaga, Tomohiro Osugi, and Shogo Haraguchi, as their main theses advisor. The names of his recent collaborators are H. Vaudry, J.C. Wingfield, G.E. Bentley, L.J. Kriegsfeld, P.J. Sharp, I.J. Clarke, R.P. Millar, S.A. Sower, Y. Muneoka, V.S. Chowdhury, J.F. Cockrem, E. Saigoh, Y.L. Son, Y. Tobari, H. Yin, K. Inoue, H. Teranishi, Y. Fukuda, T. Mizuno, M. Narihiro, K. Ishikawa, S. Ishii, O. Koizumi, M. Ueno, H. Minakata, H. Satake, E. Iwakoshi, D. Daukss, K. Gazda, T. Kosugi, G. Bedecarrats, M. Hisada, T. Kawada, N.L. McGuire, R. Calisi, N. Perfito, S. O'Brien, I.T. Moore, J.P. Jensen, G.J. Kaur, D.W. Wacker, N.A. Ciccone, I.C. Dunn, T. Boswell, S. Kim, 
Y.C. Huang, J. Reid, J. Jiang, P. Deviche, T.W. Small, M.A. Ottinger, T. Tachibana, M. Furuse, M.A. Cline, D.F. Mei, A. Mason, E.M. Gibson, S.A. Humber, S. Jain, W.P. Williams III, S. Zhao, I.P. Sari, Y. Qi, J.T. Smith, H.C. Parkington, J. Iqbal, Q. Li, A. Tilbrook, K. Morgan, A.J. Pawson, M. Murakami, T. Matsuzaki, T. Iwasa, T. Yasui, M. Irahara, M.A. Johnson, G.S. Fraley, H. Oishi, C. Klausen, C.B. Gilks, T. Yano, P.C.K. Leung, M. Binns, P.A. Cadigan, H. Lai, M. Kitani, A. Suzuuchi, V. Pham, S. Kikuyama, K. Yamamoto, A. Koda, I. Hasumuma, F. Toyoda, K. Sawada, K. Tsunekawa, P. Singh, S. Anjum, A. Krishna, R. Sridaran, S. Sethi, C.M. Chaturvedi, M.R. Jafarzadeh Shirazi, M.J. Zamiri, A. Tamadon, M. Amano, S. Moriyama, M. Iigo, K. Uchida, M. Nozaki, H. Kawauchi, M. Shahjahan, T. Ikegami, H. Okamura, H. Doi, A. Hattori, H. Ando, Y. Honda, Y. Inai, K. Inoue, H. Miyabara, T. Koyama, Y. Ogura, S. Suzuki, S. Hara, M. Kusaka, Y. Suzuki, M. Mita, K. Sasahara, H. Shikimi, S. Honda, N. Harada, M. Hatori, M. Takase, T. Hirota, M. Iitsuka, N.
Kurabayashi, K. Kokame, R. Sato, A. Nakai, T. Miyata, Y. Fukada, Y. Yamamoto, J.H. Chang, M. Sato, H. Ueda, K. Tashiro, T. Tokita, J.Y. Seong, J.L. Do Rego, J. Leprince, G. Pelletier, E.E. Baulieu, and others.

Prof. Tsutsui had not been feeling well since April 2021 and had been undergoing treatment for esophageal cancer at Hiroshima University Hospital since May 14 this year. His funeral was held in Hatsukaichi City, Hiroshima on September 18. His family received numerous condolence letters not only from Japan but also from the USA, the UK, Europe, India, Malaysia, and other countries and regions. He was an excellent mentor, colleague, and friend to many of us. We admire his scientific achievements and are sincerely grateful for his leadership in science. We believe he is now peacefully resting in heaven with his beloved wife Rieko, who passed away 8 years ago.

September 2021

Takayoshi Ubuka, Gan Medical Service Co. Ltd Kazuyoshi Ukena, Hiroshima University

\section{References}

1 Tsutsui K, Ishii S. Effects of sex steroids on aggressive behavior of adult male Japanese quail. Gen Comp Endocrinol. 1981 Aug;44(4):480-6.

2 Tsutsui K, Kawashima S, Masuda A, Oishi T. Effects of photoperiod and temperature on the binding of follicle-stimulating hormone (FSH) to testicular preparations and plasma FSH concentration in the Djungarian hamster, Phodopus sungorus. Endocrinology. 1988 Mar;122(3):1094-102.

3 Tsutsui K. Pituitary and gonadal hormonedependent and -independent induction of follicle-stimulating hormone receptors in the developing testis. Endocrinology. 1991 Jan;128(1):477-87.

4 Tsutsui K, Wingfield JC, Bottjer SW. Adenohypophysectomy in the zebra finch. Gen Comp Endocrinol. 1991 Feb;81(2):163-73.

5 Tsutsui K, Kawashima S, Saxena RN, Ishii S. Annual changes in the binding of folliclestimulating hormone to gonads and plasma gonadotropin concentrations in Indian weaver birds inhabiting the subtropical zone. Gen Comp Endocrinol. 1992 Dec;88(3):444-53.

6 Tsutsui K, Yamazaki T. Avian neurosteroids. I. Pregnenolone biosynthesis in the quail brain. Brain Res. 1995 Apr;678(1-2):1-9.

7 Ukena K, Usui M, Kohchi C, Tsutsui K. Cytochrome P450 side-chain cleavage enzyme in the cerebellar Purkinje neuron and its neonatal change in rats. Endocrinology. 1998 Jan;139(1):137-47.
8 Ukena K, Kohchi C, Tsutsui K. Expression and activity of $3 \beta$-hydroxysteroid dehydrogenase/delta5-delta4-isomerase in the rat Purkinje neuron during neonatal life. Endocrinology. 1999 Feb;140(2):805-13.

9 Furukawa Y, Kotegawa T, Tsutsui K. Effects of opioid peptides on the electrical activity of preoptic and hypothalamic neurons in the quail brain. J Exp Zool. 1995 Oct;273(2):96103.

10 Li D, Tsutsui K, Muneoka Y, Minakata H, Nomoto K. An oviposition-inducing peptide: isolation, localization, and function of avian galanin in the quail oviduct. Endocrinology. 1996 May;137(5):1618-26.

11 Sakamoto H, Ubuka T, Kohchi C, Li D, Ukena $\mathrm{K}$, Tsutsui K. Existence of galanin in lumbosacral sympathetic ganglionic neurons that project to the quail uterine oviduct. Endocrinology. 2000 Dec;141(12):4402-12.

12 Tsutsui K, Saigoh E, Ukena K, Teranishi H, Fujisawa Y, Kikuchi M, et al. A novel avian hypothalamic peptide inhibiting gonadotropin release. Biochem Biophys Res Commun. 2000 Aug;275(2):661-7.

13 Ukena K, Ubuka T, Tsutsui K. Distribution of a novel avian gonadotropin-inhibitory hormone in the quail brain. Cell Tissue Res. 2003 Apr;312(1):73-9.

14 Yin $\mathrm{H}$, Ukena K, Ubuka T, Tsutsui K. A novel $\mathrm{G}$ protein-coupled receptor for gonadotropin-inhibitory hormone in the Japanese quail (Coturnix japonica): identification, expression and binding activity. J Endocrinol. 2005 Jan;184(1):257-66.
15 Ubuka T, Ukena K, Sharp PJ, Bentley GE, Tsutsui K. Gonadotropin-inhibitory hormone inhibits gonadal development and maintenance by decreasing gonadotropin synthesis and release in male quail. Endocrinology. 2006 Mar;147(3):1187-94.

16 Ubuka T, Bentley GE, Ukena K, Wingfield JC, Tsutsui K. Melatonin induces the expression of gonadotropin-inhibitory hormone in the avian brain. Proc Natl Acad Sci USA. 2005 Feb;102(8):3052-7.

17 Sakamoto H, Ukena K, Tsutsui K. Effects of progesterone synthesized de novo in the developing Purkinje cell on its dendritic growth and synaptogenesis. J Neurosci. 2001 Aug;21(16):6221-32.

18 Sakamoto H, Mezaki Y, Shikimi H, Ukena K, Tsutsui K. Dendritic growth and spine formation in response to estrogen in the developing Purkinje cell. Endocrinology. 2003 Oct;144(10):4466-77.

19 Sasahara K, Shikimi H, Haraguchi S, Sakamoto $\mathrm{H}$, Honda S, Harada N, et al. Mode of action and functional significance of estrogen-inducing dendritic growth, spinogenesis, and synaptogenesis in the developing Purkinje cell. J Neurosci. 2007 Jul;27(28):7408-17.

20 Matsunaga M, Ukena K, Baulieu EE, Tsutsui K. $7 \alpha$-Hydroxypregnenolone acts as a neuronal activator to stimulate locomotor activity of breeding newts by means of the dopaminergic system. Proc Natl Acad Sci USA. 2004 Dec;101(49):17282-7. 
21 Kriegsfeld LJ, Mei DF, Bentley GE, Ubuka T, Mason AO, Inoue $\mathrm{K}$, et al. Identification and characterization of a gonadotropin-inhibitory system in the brains of mammals. Proc Natl Acad Sci USA. 2006 Feb;103(7):2410-5.

22 Ubuka T, Inoue K, Fukuda Y, Mizuno T, Ukena K, Kriegsfeld LJ, et al. Identification, expression, and physiological functions of Siberian hamster gonadotropin-inhibitory hormone. Endocrinology. 2012 Jan;153(1): 373-85.

23 Clarke IJ, Sari IP, Qi Y, Smith JT, Parkington HC, Ubuka T, et al. Potent action of RFamiderelated peptide- 3 on pituitary gonadotropes indicative of an hypophysiotropic role in the negative regulation of gonadotropin secretion. Endocrinology. 2008;149:5811-21.

24 Ubuka T, Lai H, Kitani M, Suzuuchi A, Pham V, Cadigan PA, et al. Gonadotropin-inhibitory hormone identification, cDNA cloning, and distribution in rhesus macaque brain. J Comp Neurol. 2009 Dec;517(6):841-55.

25 Ubuka T, Morgan K, Pawson AJ, Osugi T, Chowdhury VS, Minakata H, et al. Identification of human gonadotropin-inhibitory hormone homologs, RFRP-1 and RFRP-3, and the cognate receptor, GPR147 in the human hypothalamic pituitary axis. PLoS One. 2009;4:e8400

26 Bentley GE, Jensen JP, Kaur GJ, Wacker DW, Tsutsui K, Wingfield JC. Rapid inhibition of female sexual behavior by gonadotropin-inhibitory hormone (GnIH). Horm Behav. 2006 Apr;49(4):550-5.

27 Ubuka T, Mukai M, Wolfe J, Beverly R, Clegg S, Wang A, et al. RNA interference of gonadotropin-inhibitory hormone gene induces arousal in songbirds. PLoS One. 2012;7(1):e30202.

28 Ubuka T, Haraguchi S, Tobari Y, Narihiro M, Ishikawa K, Hayashi T, et al. Hypothalamic inhibition of socio-sexual behaviour by increasing neuroestrogen synthesis. Nat Commun. 2014;5(1):3061.

29 Johnson MA, Tsutsui K, Fraley GS. Rat RFamide-related peptide- 3 stimulates $\mathrm{GH}$ secretion, inhibits LH secretion, and has variable effects on sex behavior in the adult male rat. Horm Behav. 2007 Jan;51(1):171-80.

30 Piekarski DJ, Zhao S, Jennings KJ, Iwasa T, Legan SJ, Mikkelsen JD, et al. Gonadotropininhibitory hormone reduces sexual motivation but not lordosis behavior in female Syrian hamsters (Mesocricetus auratus). Horm Behav. 2013 Aug;64(3):501-10.
31 Son YL, Ubuka T, Millar RP, Tsutsui K. Gonadotropin-inhibitory hormone inhibits gonadotropin-releasing hormone-induced gonadotropin synthesis mediated by adenylate cyclase/cAMP/PKA-dependent ERK pathway in L $\beta$ T2 gonadotrope cells. Endocrinology. 2012;153:2332-43.

32 Ubuka T, Kim S, Huang YC, Reid J, Jiang J, Osugi $\mathrm{T}$, et al. Gonadotropin-inhibitory hormone neurons interact directly with gonadotropin-releasing hormone-I and -II neurons in European starling brain. Endocrinology. 2008 Jan;149(1):268-78.

33 Son YL, Ubuka T, Soga T, Yamamoto K, Bentley GE, Tsutsui K. Inhibitory action of gonadotropin-inhibitory hormone on the signaling pathways induced by kisspeptin and vasoactive intestinal polypeptide in $\mathrm{GnRH}$ neuronal celline,GT1-7.FASEBJ.2016Jun;30(6):2198_ 210.

34 Chowdhury VS, Yamamoto K, Ubuka T, Bentley GE, Hattori A, Tsutsui K. Melatonin stimulates the release of gonadotropin-inhibitory hormone by the avian hypothalamus. Endocrinology. 2010 Jan;151(1):271-80.

35 Son YL, Ubuka T, Narihiro M, Fukuda Y, Hasunuma I, Yamamoto K, et al. Molecular basis for the activation of gonadotropin-inhibitory hormone gene transcription by corticosterone. Endocrinology. 2014 May;155(5):181726.

36 Bentley GE, Ubuka T, McGuire NL, Chowdhury VS, Morita Y, Yano T, et al. Gonadotropin-inhibitory hormone and its receptor in the avian reproductive system. Gen Comp Endocrinol. 2008 Mar;156(1):34-43.

37 Oishi H, Klausen C, Bentley GE, Osugi T, Tsutsui K, Gilks CB, et al. The human gonadotropin-inhibitory hormone ortholog RFamide-related peptide-3 suppresses gonadotropin-induced progesterone production in human granulosa cells. Endocrinology. 2012 Jul;153(7):3435-45.

38 Osugi T, Uchida K, Nozaki M, Tsutsui K. Characterization of novel RFamide peptides in the central nervous system of the brown hagfish: isolation, localization, and functional analysis. Endocrinology. 2011 Nov;152(11): 4252-64.

39 Osugi T, Daukss D, Gazda K, Ubuka T, Kosugi T, Nozaki M, et al. Evolutionary origin of the structure and function of gonadotropininhibitory hormone: insights from lampreys. Endocrinology. 2012 May;153(5):2362-74.
40 Osugi T, Okamura T, Son YL, Ohkubo M, Ubuka T, Henmi Y, et al. Evolutionary origin of GnIH and NPFF in chordates: insights from novel amphioxus RFamide peptides. PLoS One. 2014 Jul;9(7):e100962.

41 Ubuka T, Tsutsui K. Comparative and evolutionary aspects of gonadotropin-inhibitory hormone and FMRFamide-like peptide systems. Front Neurosci. 2018 Oct;12:747.

42 Tsutsui K, Inoue K, Miyabara H, Suzuki S, OguraY,HaraguchiS.7a-hydroxypregnenolone mediates melatonin action underlying diurnal locomotor rhythms. J Neurosci. 2008 Feb;28(9):2158-67.

43 Haraguchi S, Yamamoto Y, Suzuki Y, Hyung Chang J, Koyama T, Sato $M$, et al. 7a-Hydroxypregnenolone, a key neuronal modulator of locomotion, stimulates upstream migration by means of the dopaminergic system in salmon. Sci Rep. 2015 Jul;5(1):12546.

44 Haraguchi S, Hara S, Ubuka T, Mita M, Tsutsui K. Possible role of pineal allopregnanolone in Purkinje cell survival. Proc Natl Acad Sci USA. 2012 Dec;109(51):21110-5.

45 Haraguchi S, Kamata M, Tokita T, Tashiro KI, Sato M, Nozaki M, et al. Light-at-night exposure affects brain development through pineal allopregnanolone-dependent mechanisms. eLife. 2019 Sep;8:e45306.

46 Lee YR, Tsunekawa K, Moon MJ, Um HN, Hwang JI, Osugi T, et al. Molecular evolution of multiple forms of kisspeptins and GPR54 receptors in vertebrates. Endocrinology. 2009 Jun;150(6):2837-46.

47 Osugi T, Ohtaki N, Sunakawa Y, Son YL, Ohkubo M, Iigo M, et al. Molecular evolution of kiss2 genes and peptides in vertebrates. Endocrinology. 2013 Nov;154(11):4270-80.

48 Tobari Y, Son YL, Ubuka T, Hasegawa Y, Tsutsui K. A new pathway mediating social effects on the endocrine system: female presence acting via norepinephrine release stimulates gonadotropin-inhibitory hormone in the paraventricular nucleus and suppresses luteinizing hormone in quail. J Neurosci. 2014 Jul;34(29):9803-11.

49 Kiyohara M, Son YL, Tsutsui K. Involvement of gonadotropin-inhibitory hormone in pubertal disorders induced by thyroid status. Sci Rep. 2017 Apr;7(1):1042. 